\title{
GEOGRAPHICAL VARIATION IN CAVOLINIA TRIDENTATA (MOLLUSCA, PTEROPODA)
}

\author{
by \\ S. VAN DER SPOEL \\ Institute of Taxonomic Zoology, University of Amsterdam, The Netherlands
}

\begin{abstract}
A redescription is given for five formae of Cavolinia tridentata and four formae new to science are described. The distribution of the species is given and the zoogeography of the formae is discussed.
\end{abstract}

\section{INTRODUCTION}

Studying cavoliniid pteropods it seemed necessary to change existing views on the variation in Cavolinia tridentata (MS. Forskål) (Niebuhr, 1775).

Forskål (spelling: Forsskål according to Wolff (1968)) is usually considered the author of this taxon. In my opinion this is incorrect since Petrus Forskål, according to Wolff (1968), wrote only a manuscript consisting of 1800 loose leaflets which had been sent back from the Danish Expedition to "Arabia Felix" (1761-1767). Wolff (1968) supposed that Niebuhr is not the actual author either but only the editor, while another expert, probably Johan Zoëga, made the manuscript ready for publication.

Reference to original author and year of publication is not only of administrative value but also an indication of the expert responsible for the descriptions as finally published; therefore it is proposed to maintain the citation mentioned above. Niebuhr was the only man to survive the expedition, who took responsibility for the material, the notes, the manuscripts, and for the final publication of this and other works by Forskal. Since it is unknown who made the selection from the 1800 leaflets for the manuscript and which changes, if any, were made in editing, it seems not correct to consider Forskål the only scientist responsible for the final descriptions.

The majority of the material used in this study was collected by the United States National Museum at Washington D.C. in the Atlantic Ocean and Mediterranean ${ }^{1}$ ) and in the Indo-Pacific Oceans ${ }^{2}$ ). Additional material was available from the Zoological Museum at Copenhagen and the Institute of Taxonomic Zoology at Amsterdam, collected by the Dana Expeditions and the Siboga Ex- pedition respectively.

At the time five forms of $C$. tridentata are described, viz.: forma tridentata (MS. Forskål) (Niebuhr, 1775) from the Mediterranean, forma kraussi Tesch, 1913 from the Southern Atlantic and Southern Indian Ocean, forma occidentalis (Dall, 1908) from the North Pacific, forma platea Tesch, 1948 from the Malayan waters and the forma affinis (d'Orbigny, 1836) from the East Pacific Ocean. The forma bermudensis from the Western Atlantic, the forma dakarensis from the Northeastern Atlantic, the forma atlantica from the Southern Atlantic and the forma danae from the Indian Ocean are described as new to science in the present paper. Moreover, it proved to be justified to propose the new name teschi for the forma first named platea.

\section{ACKNOWLEDGEMENTS}

The author wishes to acknowledge the kind aid of Dr. C. F. E. Roper from the United States National Museum, Washington D.C. who collected also part of the material, and of Dr. J. Knudsen from the Zoological Museum at Copenhagen who made the Dana collections available. Thanks are also due to Dr. H. Janus from the Staatliches Museum für Naturkunde at Stuttgart, Dr. A. Zilch from the Forschungs-Institut Senckenberg at Frankfurt, Mrs. A. H. Testud from the Muséum d'Histoire Naturelle at Paris, and to Mr. L. A. van der Laan who made the photographs.

\section{ZOOGEOGRAPHY}

In fig. 1 the distribution of $C$. tridentata is given together with the eleven faunal centres (indicated

1) This material was collected by the Ocean Acre Program of the U.S.N.M. supported by funds from the U.S. Navy.

2) Study of this material in the collections of the U.S.N.M. was made possible by funds of the U.S. National Science Foundation. 
by roman numerals) which will be discussed below. From this map it is clear that $C$. tridentata is a species of warm and transitional waters, absent in cold waters and rare in halostaze centres. Though cosmopolitan in its distribution, discontinuity is obvious. The absence of the species south of the Australian continent seems due to insufficient sam- pling rather than to real absence, since the southern populations from the Indian and Pacific Oceans resemble each other very closely. Geneflow between the two southern populations seems to exist and is not interrupted by a real gap in distribution.

The isolated population in the North Atlantic is

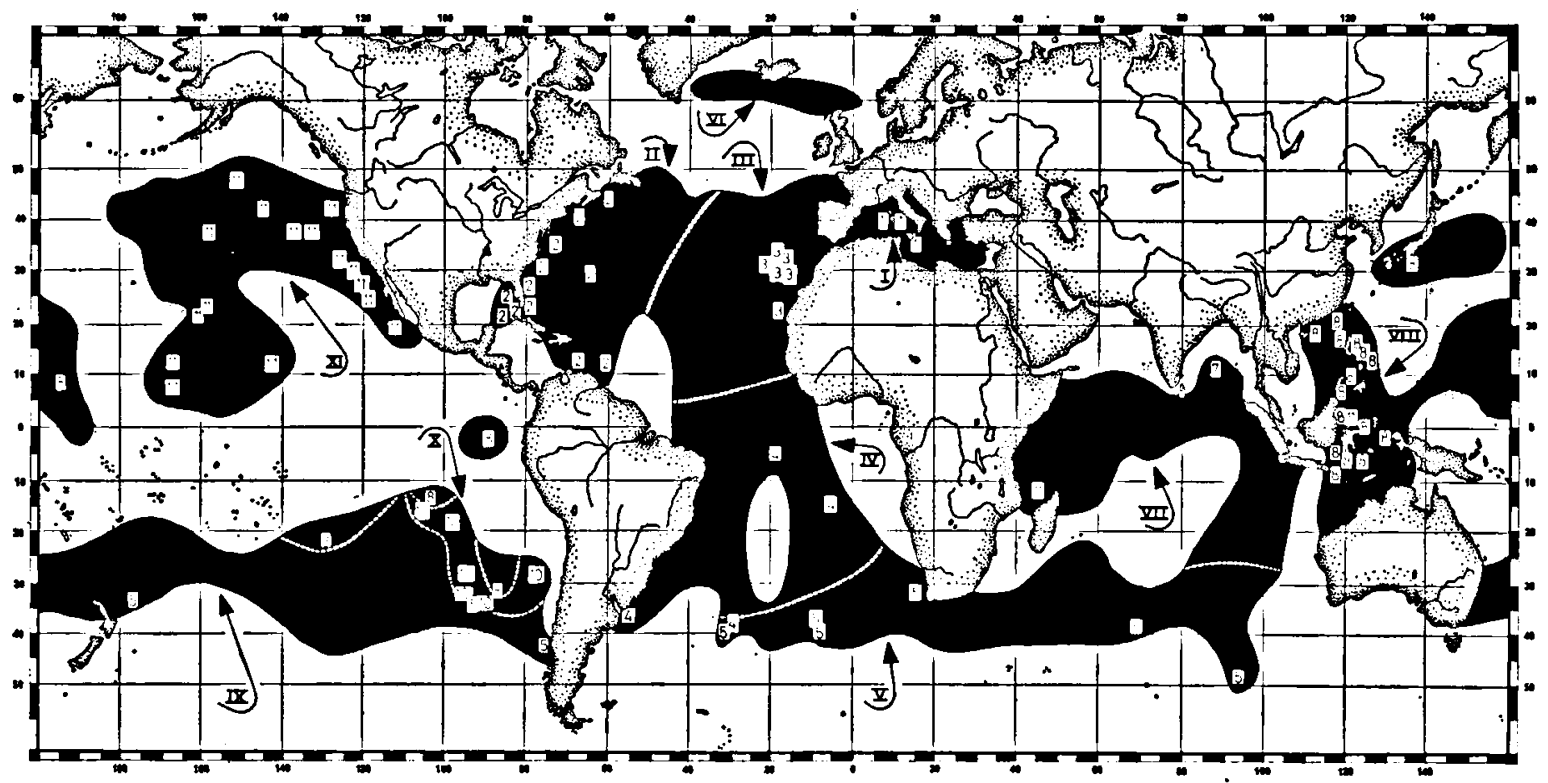

Fig. 1. Distributional map for Cavolinia tridentata with the eleven faunal centres indicated by roman numerals. The numerals in squares indicate the localities from which material is studied and refer to the numbers of the centres (cf. list page 103). The numerals indicate the formatridentata (1), bermudensis (2), dakarensis (3), atlantica (4), kraussi (5), danae (7), teschi (8), affinis (10) and occidentalis (11).

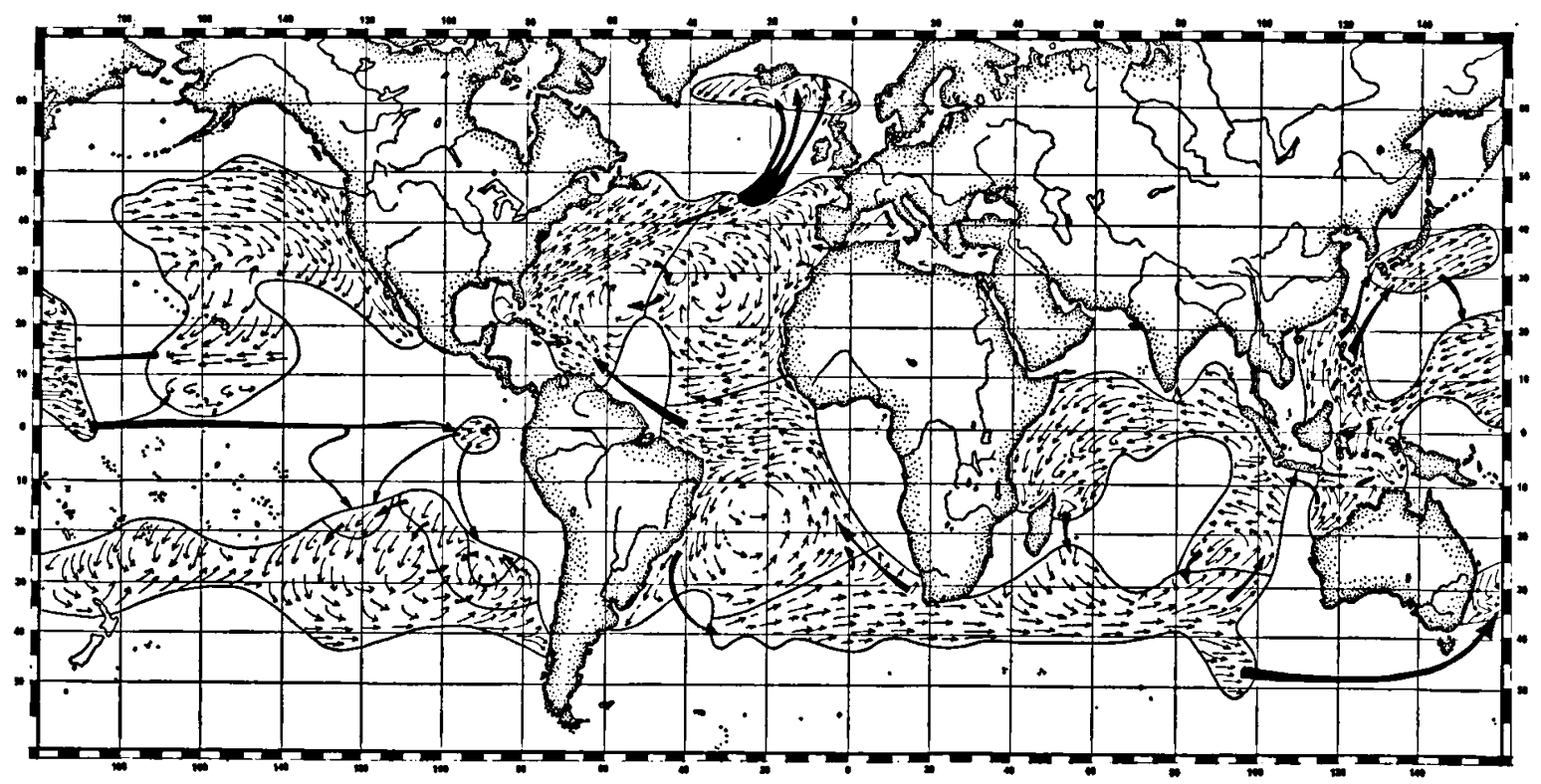

Fig. 2. Distributional map for Cavolinia tridentata (cf. fig. 1) with the water movements in the distributional areas and, thick arrows, the transport of specimens and genes in between the different centres. 
in all probability an instable population developing from time to time by migration of animals from the central Atlantic. Schiemenz (1906) described an uninterrupted distribution of the species from $60^{\circ} \mathrm{N}$ to the equator. In my opinion, however, self-supporting isolated faunal elements are not to be expected in the faunal centres VI and IX.

The populations around the southern islands of Japan and around the Galapagos Islands take an isolated position. Still they are not considered as separate faunal elements. The populations south of Japan are in all probability related to, or descending from the faunal centre VIII while the same is assumed for the populations around the Galapagos Islands. Specimens studied from both areas do not differ in characters from those investigated from the faunal centre VIII.

Truly different, self-supporting and rather isolated faunal elements are found in the centres I, II, III (with VI), IV, V (with IX), VII, VIII, $X$ and XI. These faunal centres are considered hydrographically determined areas where special planktonic faunas occur and where the existing species have developed special formae, as representative elements of these faunas. Between the centres, areas are found where the formae interbreed and merge gradually into each other.

Concerning the Northern and Eastern Pacific, McGowan (unpubl.) stated: "The indications are, from the SIO-POFI data that $C$. tridentata var. affinis is the commonest form present in the Eastern North Pacific. However, it seems possible that these varieties are merely growth stages since there is a regular size increase and gradation of form from one (var. platea) to the other (var. affinis and var. kraussi) and populations of var. kraussi did occur in areas where var. affinis were caught at neighbouring stations".

McGowan (unpubl.) was correct when considering the var. platea a mere growth stage. Tesch (unpubl.; 1948) described this variety from Malayan, Indian and Pacific waters but it occurs also in the Atlantic; and it is the growth stage of this species which I (van der Spoel, 1967; 1970) called the minute stage (fig. 5k). It should be mentioned that McGowan did not distinguish between the formae occidentalis and affinis. From the area of centre IX, Dana material and material of the collections of Dall were studied, which proved the forma kraussi to occur in this centre. The forma affinis is a typical element of the centre $\mathrm{X}$ overlapping partly the centre IX. This area in the South East Pacific is rather complicated as repre- sentatives of the centre VIII are also met here. Probably with the Equatorial Counter Current and the northern parts of the West Wind Drift, transport of populations towards this area is possible (fig. 2).

Material from the Albatross Expeditions and the original material described by Dall $(1908 ; 1921)$ proved that the forma occidentalis occurs in the faunal centre XI. This forma is not mentioned by McGowan (unpubl.), in all probability he considered this forma synonymous with the forma affinis. Tesch (1904) did not mention the forma occidentalis either, which seems logical as only the forma teschi (see below) is found in the IndoMalayan waters. But the forma affinis is given by Tesch (1904) as occurring in the Indo-Malayan Archipelago. The specimen considered by Tesch to belong to the forma affinis and collected at Siboga station 116 is reexamined and it proved to resemble most the forma occidentalis. The occurrence of this forma at $00^{\circ} 58.5^{\prime} \mathrm{N} 122^{\circ} 42.5^{\prime} \mathrm{E}$ (Siboga sta. 116) is exceptional, probably due to transport through the Pacific by Equatorial Currents.

In the present study the formae occidentalis and affinis are both considered valid. The forma affinis as described by d'Orbigny (1836) and discussed by Boas (1886) consists of the two formae mentioned. The most typical difference between affinis and occidentalis is not the curvature of the caudal spine as described and pictured by Boas (1886), but it is formed by the greater average size and the less perfect round shape of the ventral surface in affinis. The original description by d'Orbigny is based on a specimen with the embryonic shell intact, and it is only this embryonic shell which strongly bends dorsad, which is normal for both the formae occidentalis and affinis.

The populations of Indo-Malayan waters are clearly separated from the otherPacific populations. Microevolution in the Pacific has not led to subspecies formation as the mixture of populations by currents is still too intensive, but the differences between the Indo-Pacific formae are greater than those between the Atlantic formae.

Representatives of the Atlantic and Indian Ocean have incorrectly been considered always to be identical to the Mediterranean form. The populations from the southern oceans, found in the centres V and IX, consist of the forma kraussi, and are usually considered as such; but the populations of the Indian Ocean and North Atlantic Ocean differ also strongly in shape and size from the Mediterranean ones, which was usually not recog- 
nized. The first who recognized differences between Atlantic and Indian Ocean populations was Fryer (1869). The zoogeography and description of the three species which are recognized by Fryer are, however, too vague to be reproduced here. In the synonymy to the formae the names used by Fryer (loc.cit.) are given where possible. The Mediterranean populations show special characters, which is explained by the isolated character of this ocean basin. Less easily explained are the differences between the faunal elements of the centres II, III and IV. These centres are not at all isolated. The centre IV may coincide with the South Atlantic halostaze limited in the north by the Equatorial Current and in the south by the Tropic Front. Probably different ecological selective pressures are responsible for the differences between the populations in the areas II and III. An indication for clinal variation is not found in the North Atlantic; therefore the ecological or climatological influences could not be traced.

The special characters of the forma living in centre VII can be explained by the relatively isolated position of this warm water centre separated by land from the other warm water areas. The only contact with other representatives of the present species of this faunal element is formed by the forma kraussi from transitional waters.

\section{TAXONOMY}

The total number of different formae which may be recognized in $C$. tridentata is nine, viz.: Cavolinia tridentata forma tridentata

from faunal centre I

Cavolinia tridentata forma bermudensis

from faunal centre II

Cavolinia tridentata forma dakarensis

from faunal centre III (and VI)

Cavolinia tridentata forma atlantica

from faunal centre IV

Cavolinia tridentata forma kraussi

from faunal centre $\mathrm{V}$ (and IX)

Cavolinia tridentata forma danae

from faunal centre VII

Cavolinia tridentata forma teschi

from faunal centre VIII

Cavolinia tridentata forma affinis

from faunal centre $X$

Cavolinia tridentata forma occidentalis

from faunal centre XI

The description of these infra-subspecific taxa does not make it easier to identify specimens but more accurate studies on the biology can be executed with this more accurate subdivision of taxa. For the forma concept one is referred to van der Spoel (1971).

In this paper the name teschi is proposed for the Indo-Malayan populations replacing the name platea, though the growth stage mentioned by Tesch (unpubl.; 1948) is undoubtedly a young stage of the forma living there. The name given by Tesch is to be considered a nomen nudum as it is not accompanied by a description in the 1948 publication.

Affinis and kraussi are treated in the present paper as formae though they do sometimes occur sympatrical as stated also by McGowan (unpubl.). But when they actually occur sympatrically they show interbreeding as indicated by the high number of intermediates. In some samples I found two formae together without their intermediates but these samples are always from open net hauls from greater depth.

Most of the faunal centres and their populations need a more detailed study than is possible at this moment but a few remarks can be made already. The "typical" $C$. tridentata form is considered restricted to the Mediterranean; Cavolinia tridentata was originally described from material collected in the Mediterranean. The forma kraussi shows not only interbreeding with the forma affinis in the Pacific as mentioned, but also with the forma atlantica in the Atlantic and with the forma danae in the Indian Ocean. Populations in the Caribbean Sea near $10^{\circ} \mathrm{N}$ show strong influences of the forma atlantica. Consequently strong interbreeding among the formae bermudensis and atlantica is to be expected, which may be explained by a transport by Equatorial Currents of the latter forma. The forma dakarensis may show in the periphery of its range a gradual changeover into the formae atlantica and bermudensis. A clear interbreeding between the formae tridentata and dakarensis is not expected at the moment because a changeover between the two could not be demonstrated. The contact between the faunal centres $V$ and IX and their populations is already mentioned.

The forma occidentalis from the faunal centre XI shows a clear affinity to the forma affinis from faunal centre X. From a morphological point of view one should be inclined to consider the forma occidentalis as a forma of Cavolinia uncinata (Rang, 1829), an idea already given by Tesch (1904). The formae affinis and teschi however, constitute 
clear intermediate forms to the other representatives of $C$. tridentata.

The forma teschi penetrates the East Pacific north of $25^{\circ} \mathrm{S}$ and interbreeds there with the forma affinis and kraussi which gives the teschi populations east of $180^{\circ} \mathrm{W}$ another appearance than those from the Indo-Malayan waters but there is no reason to distinguish between eastern and western teschi populations as a boundary between the two is absolutely absent. Closely related to teschi is the forma danae from the Indian Ocean, though frequent interbreeding is not to be expected as the distribution is discontinuous. Contact of the forma danae with the forma atlantica south of the African continent is at least restricted as the forma kraussi has its northern limit north to the Cape of Good Hope.

From the above mentioned relations one can conclude that there are two clearly separate formae kraussi and tridentata, an Atlantic group of three formae viz.: atlantica, bermudensis and dakarensis, an Indian Ocean group of two formae viz.: danae and teschi of which teschi is also found in the Pacific and an endemic Pacific group composed of affinis and occidentalis.

Size differences between the formae are not of discriminating value. The formae bermudensis, teschi, danae and kraussi are of an average size, the forma dakarensis is the largest forma while the formae tridentata, atlantica, occidentalis and affinis constitute a group of smaller types (fig. 3). Clinal variation in size, however, is not concerned. In fig. 2 the distribution of the formae is given with possible movements of specimens in between the centres indicated by thick arrows. Water current patterns in the area of distribution are given with thin arrows. From this map it is clear that exchange of specimens, and as a consequence of genes, may exist between all the faunal centres. This explains the great resemblance between the formae and the identity within populations.

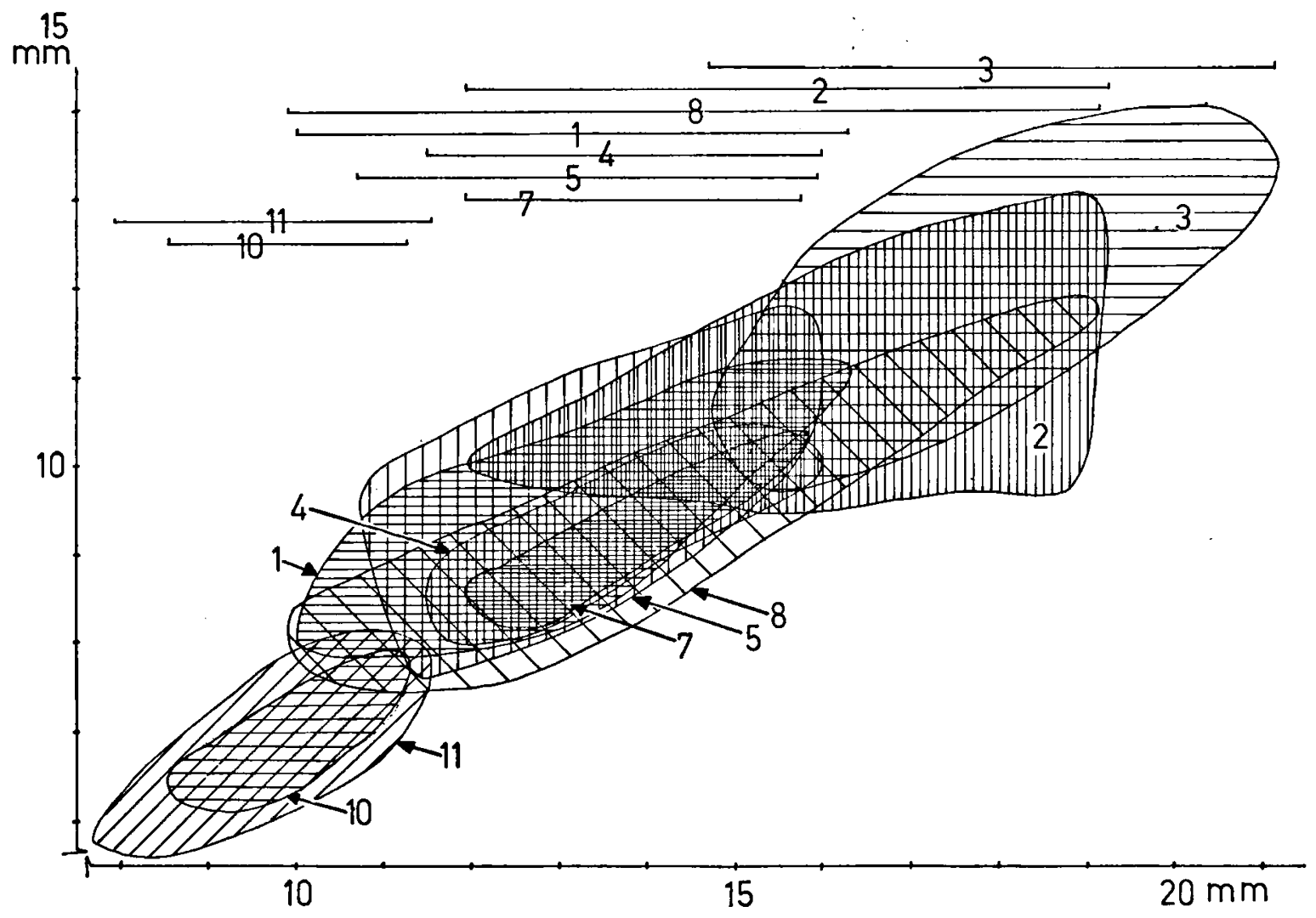

Fig. 3. Length-width relation for Cavolinia tridentata forma tridentata (1), forma bermudensis (2), forma dakarensis (3), forma atlantica (4), forma kraussi (5), forma danae (7), forma teschi (8), forma affinis (10) and forma occidentalis (11) in $\mathrm{mm}$. 


\section{DESCRIPTION OF THE FORMAE OF CAVOLINIA TRIDENTATA}

In the respective lists of material the localities are given only for measured or figured specimens, while in fig. 1 all identified material is represented by a square. Abbreviations used in the lists below are U.S.N.M. for United States National Museum at Washington D.C., Z.M.U.C. for the Zoological Museum at Copenhagen and Z.M.A. for the Institute of Taxonomic Zoology at Amsterdam, while Med. stands for the Mediterranean cruises executed in 1971 by the U.S.N.M.

\section{Cavolinia tridentata forma tridentata}

(MS. Forskål) (Niebuhr, 1775).

Figs. 4a;6c.

\section{Synonymy}

Monoculus telemus Linnaeus, 1758: 635; Anomia tridentata (MS. Forskål) Niebuhr, 1775: 124, 1776: pl. 40, figs. B, b1, b2; Cavolinia natans Abildgaard, 1791: 175; Cavolinia tridentata (part) Philippi, 1853: 290; Hyalaea tridentata (part) Fryer, 1869: 266; Cavolinia tridentata forma tridentata (part) van der Spoel, 1967: 94, fig. 89.

Material

$40^{\circ} 32^{\prime} \mathrm{N} 12^{\circ} 28^{\prime} \mathrm{E}$ (Med. 3-20 M, U.S.N.M.) (fig. 4a); $40^{\circ} 23^{\prime} \mathrm{N} 12^{\circ} 43^{\prime} \mathrm{E}$ (Med. 3-24 M, U.S.N.M.); $40^{\circ} 26^{\prime} \mathrm{N}$ $12^{\circ} 33^{\prime} \mathrm{E}$ (Med. 3-18 P, U.S.N.M.); $40^{\circ} 27^{\prime} \mathrm{N} 12^{\circ} 52^{\prime} \mathrm{E}$ (Med. 3-3 B, U.S.N.M.); Napels (coll. Schepman, Z.M.A.); Messina (Z.M.A.).

\section{Description}

The shell of hyaline or opaque nature is triangular in ventral view, showing a relatively flat, dorsal surface with moderately developed dorsal ribs. The dorsal lip is separated from the dorsal surface by a prominent arch-shaped rib between the aperture closing mechanisms. The dorsal lip is rounded and sometimes even pointed, so that the aperture is triangular in shape. Lateral sides show no keels. The lateral spines are directed sligthly caudad. The shell margin between caudal and lateral spines is regularly concave. The ventral surface is vaulted. The structures on the shell consist of clearly developed transversal ribs and faint growth lines. The shell shows a chestnut brown colour over its entire surface. The shell length varies between 10.0 and $18.0 \mathrm{~mm}$, its width varies between 7.5 and 11.5 $\mathrm{mm}$, the averages are 11.2 and $8.5 \mathrm{~mm}$ respectively.

\section{Range}

This form is endemic for the Mediterranean (centre I). Type locality: The type material could not be traced. The species, and this forma is originally described from the Mediterranean.
Cavolinia tridentata forma bermudensis $n$. forma. Figs. 4d;6a.

\section{Synonymy}

This forma is usually named $C$. tridentata in previous works or considered to belong to the typical subspecies or forma as it has never been recognized as a separate forma.

\section{Material}

Off Sambo Reef, Fla. (U.S.N.M. 357035); Albatross sta. 2385 (U.S.N.M. 614075); off Pelican Isl., Barbados (U.S.N.M. 502290); Barbados (U.S.N.M. 199037); off Havana, Cuba (U.S.N.M. 199041); several stations off Bermuda made during the Ocean Acre Program (U.S. N.M.); George Banks (U.S.N.M. 52104); Gulf of Mexico (U.S.N.M. 223656); $27^{\circ} 20^{\prime} \mathrm{N} 51^{\circ} 54^{\prime} \mathrm{W}$ (Dana sta. 1325 III, Z.M.U.C.).

\section{Description}

The hyaline or opaque shell shows a slightly vaulted dorsal surface, with moderately or even poorly developed ribs. The dorsal lip is separated from the dorsal surface by a well developed archshaped rib. In ventral view the lateral margins of upper lip and shell-body form a smooth regular line without clear incisions near the base of the dorsal lip. The upper aperture lip is rounded. The lateral sides show no keels and the lateral spines do not project caudad. The caudal spine is straight, while the shell margins between the caudal and lateral spines are composed of a concave and a straight section. The ventral side is moderately vaulted. The aperture has a triangular shape. The shell structure consists of tiny transversal ribs and nearly invisible growth lines. The whole shell is yellowish-brown in colour. The shell length varies between 12.0 and $19.5 \mathrm{~mm}$, while the width varies between 9.5 and $13.5 \mathrm{~mm}$, the averages are 15.8 and $10.2 \mathrm{~mm}$ respectively.

\section{Range}

The forma occurs in the North West Atlantic (centre II). Type locality: Off Martha's Vingard, U.S. Fish. Com. sta. 876. The holotype (U.S.N.M. 38334) (fig. 4d) is kept dry in the United States National Museum, together with four (U.S.N.M. $703761,703762,703763,703764)$ paratypes, one paratype is kept in the Institute of Taxonomic Zoology at Amsterdam.

Cavolinia tridentata forma dakarensis $\mathrm{n}$. forma. Figs. 4b;6b.

\section{Synonymy}

This forma is usually referred to as Cavolinia tridentata in previous works. Hyalaea tridentata (part) Fryer, 1869: 266, fig. 1. 
Material

Atlantic (U.S.N.M. 127281); $29^{\circ} 13^{\prime} \mathrm{N} 14^{\circ} 42^{\prime} \mathrm{W}$ (Dana sta. 4017 XI, Z.M.U.C.); $28^{\circ} 09^{\prime} \mathrm{N} 15^{\circ} 19^{\prime} \mathrm{W}$ (Dana sta. 4014 IV, Z.M.U.C.); $34^{\circ} 15^{\prime} \mathrm{N} 16^{\circ} 52^{\prime} \mathrm{W}$ (Dana sta. 1141 IV, XVI, XX, Z.M.U.C.); $31^{\circ} 30^{\prime} \mathrm{N} 12^{\circ} 12^{\prime} \mathrm{W}$ (Dana sta. 4018 I, Z.M.U.C.); $30^{\circ} 17^{\prime} \mathrm{N} 20^{\circ} 44^{\prime} \mathrm{W}$ (Dana sta. 1152 V, Z.M.U.C.).

\section{Description}

The usually hyaline or sometimes opaque shell shows a rather flat dorsal surface with moderately developed ribs. The dorsal lip is separated from the dorsal side by a moderately or poorly developed arch-shaped rib between the closing mechanisms. The lateral sides have no lateral keels, and the margin of upper lip and shell-body forms an irregular line by the incisions at the base of the lip. This dorsal lip is truncated so that a more or less straight upper border of about $4 \mathrm{~mm}$ length is found. The aperture is irregular, triangular in shape. The caudal spine is straight and relatively long. The lateral spines curve caudad. The margin of the shell between the caudal and lateral spines shows a concave and a straight part. The ventral side is moderately vaulted. The structure on the shell consists of faint growth lines and a very faint transversal striation. The yellowish-brown hue over the shell is less intense on the dorsal lip and along the lateral sides. The shell length varies between 14.5 and $21.5 \mathrm{~mm}$, the width varies between 9.5 and $14.5 \mathrm{~mm}$, the averages are 16.9 and $11.4 \mathrm{~mm}$ respectively.

\section{Range}

This forma occurs in the Northeastern Atlantic (centres II and VI). Type locality: $32^{\circ} 55^{\prime} \mathrm{N} 21^{\circ} 51^{\prime}$ W, Dana sta. 1148 VII. The holotype and 10 paratypes (fig. 4b) are kept in alcohol in the Zoological Museum at Copenhagen; 2 paratypes are preserved in the Institute of Taxonomic Zoology at Amsterdam.

Cavolinia tridentata form atlantica $n$. forma. Figs. 4c; 6i.

\section{Synonymy}

This forma is usually named $C$. tridentata in previous works.

\section{Material}

South Atlantic (U.S.N.M. 127289); $5^{\circ} \mathrm{S} 20^{\circ} \mathrm{W}$ (U.S. N.M. 169292); $40^{\circ} \mathrm{S} 30^{\circ} 35^{\prime} \mathrm{W}$ (Walter Herwig Exped. 1971 sta. 371 II, U.S.N.M.).

\section{Description}

The hyaline or less frequently opaque shell shows a moderately vaulted dorsal surface. The central rib on the dorsal side is well developed, the lateral ribs are much less developed. A well developed arch-shaped rib is found at the base of the dorsal lip. The lateral sides are not provided with keels. The lateral spine points are directed slightly caudad, the caudal spine is short and straight. The shell margin between caudal and lateral spines is concave with a more or less straight horizontal section. The ventral side is moderately vaulted. The aperture is triangular in shape. The dorsal aperture lip is rounded or it may be provided with a small additional part with a short straight section of about $3 \mathrm{~mm}$ length. The growth lines on the shell are faint and the transversal striation on the shell is poorly developed. A light-brown hue covers nearly the whole shell. The shell length varies between 11.5 and $16.0 \mathrm{~mm}$, the width varies between 8.0 and $10.5 \mathrm{~mm}$, with averages of 15.2 and $9.9 \mathrm{~mm}$ respectively.

\section{Range}

This forma occurs in the Southern Atlantic between $5^{\circ} \mathrm{N}$ and $40^{\circ} \mathrm{S}$ (centre IV). Type locality: St. Helena, coll. Turton. The holotype (U.S.N.M. 123920) (fig. 4c) and one paratype (U.S.N.M. 703765) is kept dry in the United States National Museum, one paratype is kept dry in the Institute of Taxonomic Zoology at Amsterdam.

\section{Cavolinia tridentata forma kraussi Tesch, 1913.}

Figs. 4e; 6f.

\section{Synonymy}

Hyalaea truncata (non Lesueur, 1821) Krauss, 1848: 34, pl. 2, fig. 12; Hyalaea teniobranchia (part) Fryer, 1869: 266, fig. 2; Cavolinia tridentata kraussi Tesch, 1913: 51; Cavolinia tridentata forma kraussi van der Spoel, 1967: 97, fig. 94; Cavolinia tridentata var. kraussi McGowan, unpubl.: 129.

\section{Material}

$40^{\circ} 00^{\prime} \mathrm{S} 30^{\circ} 35^{\prime} \mathrm{W} ; 39^{\circ} 53^{\prime} \mathrm{S} 21^{\circ} 33^{\prime} \mathrm{W}$; $40^{\circ} 35^{\prime} \mathrm{S} 09^{\circ} 57^{\prime} \mathrm{W}$; $40^{\circ} 34^{\prime} \mathrm{S} 09^{\circ} 50^{\prime} \mathrm{W} ; 40^{\circ} 03^{\prime} \mathrm{S} 07^{\circ} 30^{\prime} \mathrm{W} ; 40^{\circ} 02^{\prime} \mathrm{S} 07^{\circ} 28^{\prime} \mathrm{W}$ $40^{\circ} 01^{\prime} \mathrm{S} 07^{\circ} 25^{\prime} \mathrm{W} ; 38^{\circ} 06^{\prime} \mathrm{S} 01^{\circ} 12^{\prime} \mathrm{E} ; 34^{\circ} 25^{\prime} \mathrm{S} 14^{\circ} 47^{\prime} \mathrm{E}$; $24^{\circ} 22^{\prime} \mathrm{S} 00^{\circ} 29^{\prime} \mathrm{E}$, Walter Herwig Exped. 1971, sta. $371 \mathrm{II}$, 380 III, 399 II, 402 I, 402 II (fig. 4e), 402 III, 409 I, 419 I and 439 I respectively (U.S.N.M.); $33^{\circ} 36^{\prime}$ 'S $179^{\circ}$ 10'W (Dana sta. 3629 I, Z.M.U.C.); West of Tristan da Cunha (Z.M.A.).

\section{Description}

The hyaline or opaque shell shows a slightly vaulted dorsal surface with three well developed longitudinal ribs and two less prominent ribs along the lateral sides. The dorsal aperture lip is separated from the dorsal side by a prominent archshaped rib between the closing mechanisms. The aperture lip is strongly truncated, usually even 
showing two anterior projections. The lateral sides are provided with strong side keels composed by thin "wings" of the ventral and the dorsal shell surface. The lateral spine points are directed caudad. The caudal spine is straight. The shell margin between the caudal and lateral spines is irregularly concave. The ventral side is strongly vaulted. The shell aperture is trapezoid in shape. The structure on the shell consists of growth lines and transversal ribs on the ventral side which are very variable, sometimes they are coarse, sometimes faint. The colour of the shell consists of a brown to darkbrown or purple pattern over the ventral and dorsal side. The dorsal aperture lip is always lighter in colour and the lateral keels are whitish. The shell length varies between 10.5 and $16.0 \mathrm{~mm}$, the width varies between 8.0 and $10.5 \mathrm{~mm}$, with averages of 13.3 and $10.2 \mathrm{~mm}$ respectively.

Range

This forma occurs in the Subantarctic waters of Atlantic, Indian and Pacific Oceans (centre V and IX). Type locality: Vals Bay (South Africa). The type material, formerly kept in the Staatliches Museum für Naturkunde at Stuttgart, has been lost (Dr. Janus in lit.).

Cavolinia tridentata forma danae $\mathrm{n}$. forma.

Figs. 5f;6e.

\section{Synonymy}

This forma is usually named $C$. tridentata in previous works and Tesch (1948) probably used var. platea for part of this taxon. Hyalaea affinis (non d'Orbigny, 1836, non Sowerby, 1878) (part) Fryer, 1869: 266.

\section{Material}

Gulf of Bengal (U.S.N.M. 12726); Indian Ocean (U.S.N.M. 127290; this sample shows some characters of the next forma).

\section{Description}

The shell is hyaline or opaque with a rather flat dorsal surface, provided by nearly invisible longitudinal ribs. The dorsal lip is separated from the dorsal side by a very flat but distinct arch-shaped rib. The lateral sides have no keels, the lateral spine tops are directed caudad. The dorsal aperture lip is truncated giving rise to a straight upper margin of about $4 \mathrm{~mm}$. The relatively long caudal spine is straight and the shell margin between caudal and lateral spines is concave. The ventral side is moderately vaulted. The growth lines and transversal ribs on the ventral surface are not distinct. The aperture is trapezoid. The colour pattern consists of a yellowish-brown irregularly distribut- ed over the shell. Shell length varies between 12.0 and $16.0 \mathrm{~mm}$ and width varies between 8.0 and $10.5 \mathrm{~mm}$, with averages of 14.8 and $9.5 \mathrm{~mm}$ respectively.

Range

This forma is endemic in the Indian Ocean north of $25^{\circ} \mathrm{S}$ (centre VII). Type locality: $14^{\circ} 16^{\prime} \mathrm{S} 41^{\circ} 48^{\prime}$ E, Dana Exped., sta. 3951 IV. The holotype (fig. 5f) is kept in alcohol in the Zoological Museum at Copenhagen, two paratypes are preserved in alcohol in the Institute of Taxonomic Zoology at Amsterdam.

Cavolinia tridentata forma teschi $n$. forma.

Figs. 5g, j, k; 6d.

\section{Synonymy}

Hyalaea affinis (non d'Orbigny, 1836, non Sowerby, 1878) (part) Fryer, 1869: 262, 266, pl. 21, fig. 3; Cavolinia tridentata platea (part) Tesch, 1948: 25, fig. 21 E-F; Cavolinia tridentata forma platea (part) van der Spoel, 1967: 96, fig. 93; Cavolinia tridentata var. platea (part) McGowan, unpubl.: 129.

\section{Material}

Ally Isl. Ujae Atoll (U.S.N.M. 607392); $7^{\circ} 24^{\prime}$ S $118^{\circ} 15.2^{\prime} \mathrm{E}$ (fig. $5 \mathrm{j}$ ); $52.9^{\circ} \mathrm{S} 119^{\circ} 56.7^{\prime} \mathrm{E} ; 0^{\circ} 34.6^{\prime} \mathrm{N} 119^{\circ}$ $8.5^{\prime} \mathrm{E} ; 5^{\circ} 43.5^{\prime} \mathrm{N} 119^{\circ} 40^{\prime} \mathrm{E} ; 6^{\circ} 11^{\prime} \mathrm{N} 120^{\circ} 37.5^{\prime} \mathrm{E} ; 2^{\circ} 40^{\prime} \mathrm{S}$ $128^{\circ} 37.5^{\prime} \mathrm{E}$; $5^{\circ} 39^{\prime} \mathrm{S} 122^{\circ} 12^{\prime} \mathrm{E}$; $6^{\circ} 24^{\prime} \mathrm{S} 124^{\circ} 39^{\prime} \mathrm{E}$; Banda, Siboga sta. 45, 52, 88, 95, 100, 178, 208, 221 and 240 respectively (Z.M.A.); $3^{\circ} 40^{\prime} 30^{\prime \prime} \mathrm{N} 137^{\circ} 53^{\prime} \mathrm{E}$ (Dana sta. 3751 III, Z.M.U.C.) (fig. 5k).

\section{Description}

The hyaline or opaque shell shows a rather flat dorsal surface with slightly developed longitudinal ribs. The dorsal aperture lip is separated by a moderately developed rib forming an arch between the closing mechanisms of the aperture. This dorsal aperture lip is rounded, only in some of the older specimens provided by a small additional part giving rise to a truncated part with a straight margin of only about $3 \mathrm{~mm}$. The lateral sides have no keels, the lateral spine points are directed caudad. The caudal spine is straight and the shell margin between this spine and the lateral spines is concave. The ventral side is moderately vaulted. The wide shell aperture has a lunar shape. Growth lines are very faintly developed and the transversal striae on the ventral side are very thin, nowhere disturbing the smooth character of the shell. The colour pattern consists of a yellowish-brown hue over the shell, the central parts of ventral and dorsal side are usually lighter than the remaining shell parts. The shell length varies between 10.0 and $19.0 \mathrm{~mm}$, the width varies between 7.5 and 


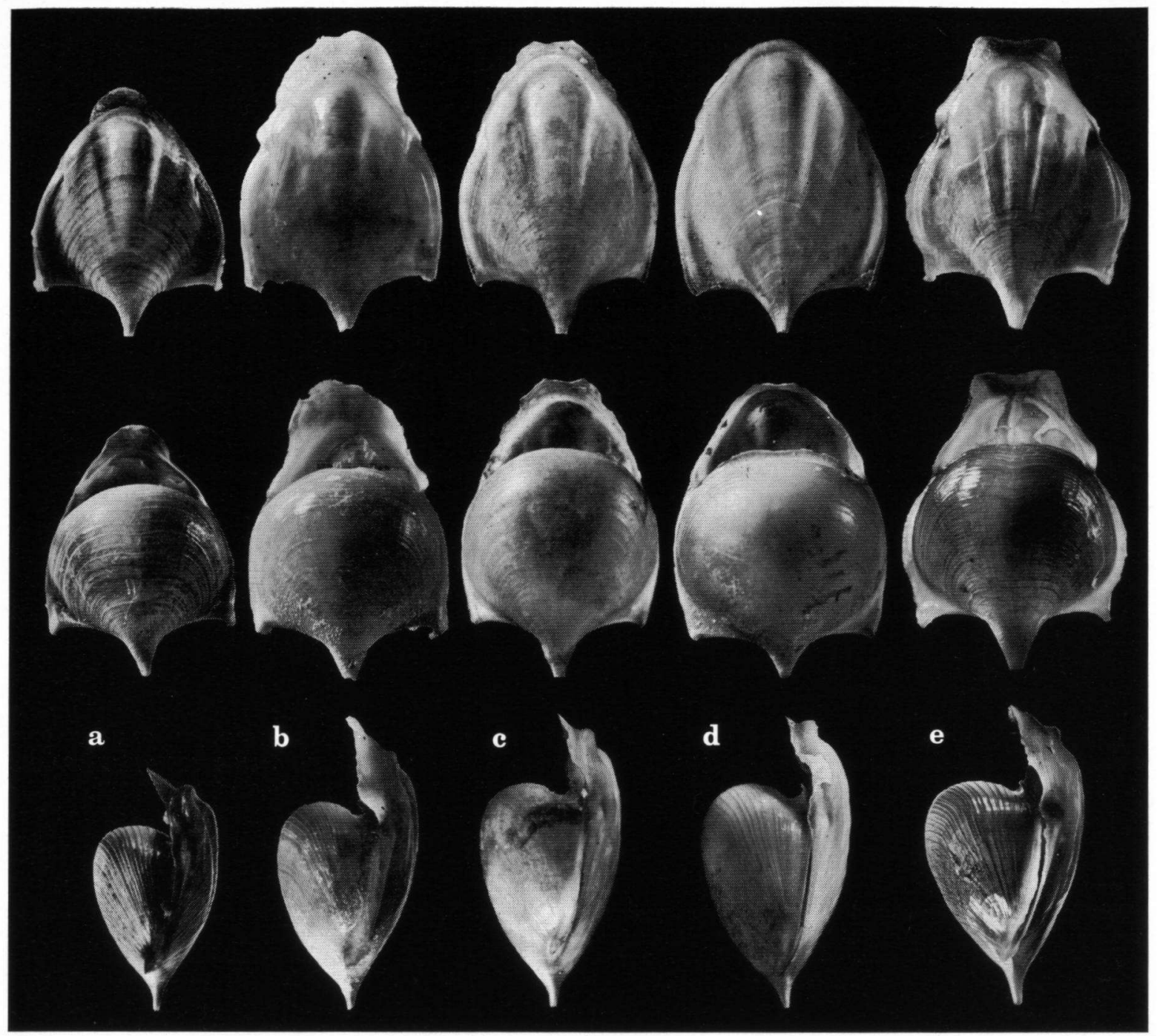

Fig. 4. Photographs of shells of Cavolinia tridentata (magnification $\times 3$ approx.); in the upper row dorsal views in the middle row ventral views and in the lower row lateral views of the formae tridentata (a), dakarensis (b), atlantica (c), bermudensis (d), and kraussi (e).

$12.0 \mathrm{~mm}$, with averages of 13.7 and $8.9 \mathrm{~mm}$ respectively.

Range

This forma is found in the Indo-Malayan waters, Equatorial and Tropical Pacific (centre VIII). Type locality: $5^{\circ} 40.7^{\prime} \mathrm{S} 120^{\circ} 45.5^{\prime} \mathrm{E}$ (Siboga sta. 211). The holotype (fig. $5 \mathrm{~g}$ ) and three paratypes are kept dry in the Institute of Taxonomic Zoology at Amsterdam.

Tesch (1948) did not publish a description, and as he did never indicate type material the name "platea" is in fact a nomen nudum. As a nomen nudum is not available according to the code the name teschi is proposed for this forma new to science in honour to the late Dr. J. J. Tesch.
To show the development of the shell during its growth a photograph (fig. 5k) of a young shell, with an animal in minute stage (cf. van der Spoel, 1967) and a photograph (fig. 5j) of a more developed but still not yet fullgrown specimen is given. It was a growth stage like given in fig. 5k on which Tesch (unpubl.; 1948) based the variety "platea".

Cavolinia tridentata forma affinis (d'Orbigny, 1836).

Figs. 5i; 6 h.

\section{Synonymy}

Hyalaea affinis (non Sowerby, 1878, non Fryer, 1869) (part) d'Orbigny, 1836: 91 (1846), pl. 5, figs. 6-10; Hyalaea tridentata var. affinis (part) Boas, 1886: 116, 212, fig. 100; Cavolinia tridentata var. affinis (part) 


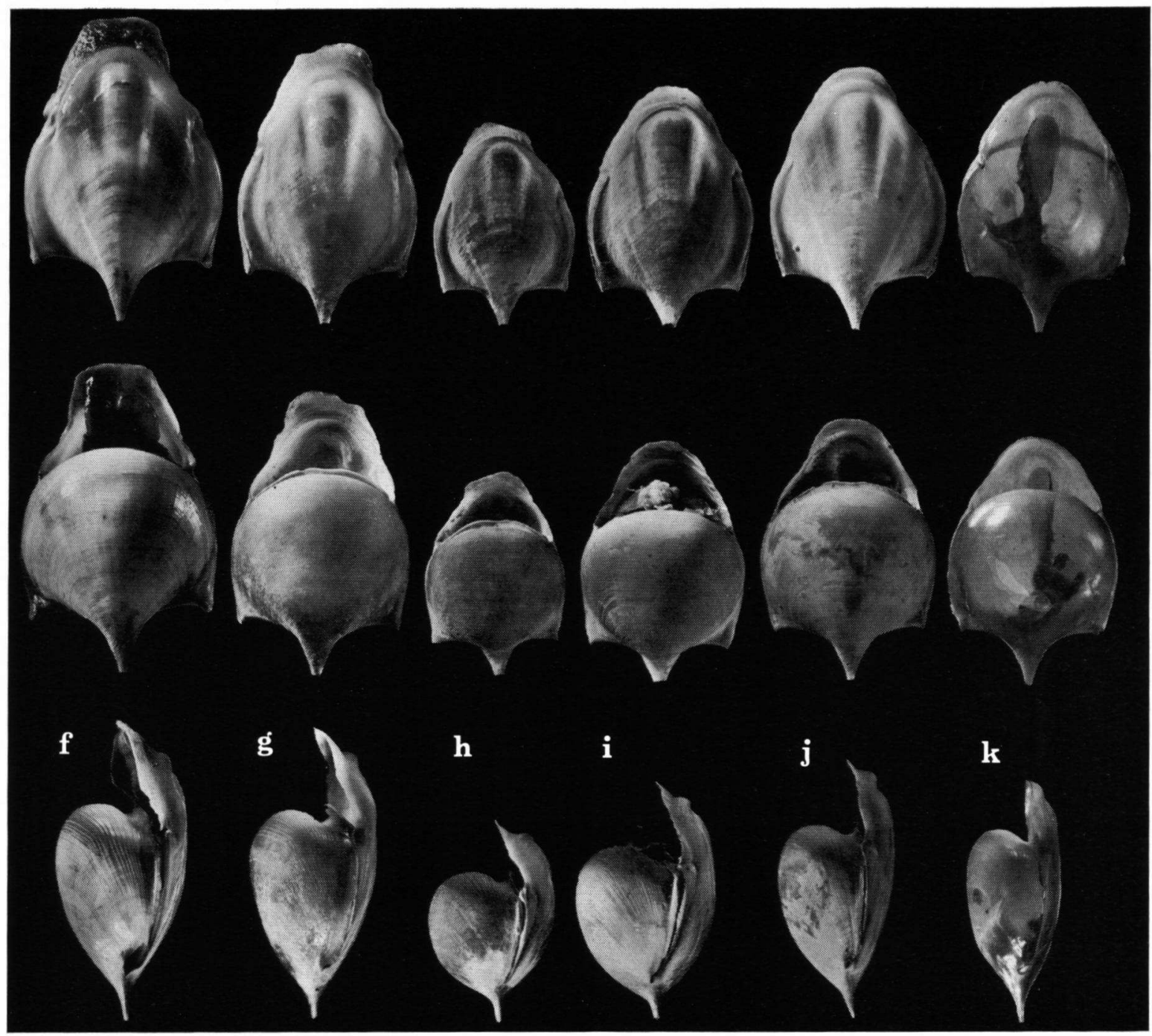

Fig. 5. Photographs of shells of Cavolinia tridentata (magnification $\times 3$ approx.); in the upper row dorsal views, in the middle row ventral views and in the lower row lateral views of the formae danae (f), teschi (g), occidentalis (h), affinis (i), early adult stage of teschi (j), and the minu te stage of teschi (k).

Tesch, 1904: 39, pl. 2, fig. 32; McGowan, unpubl., 129; Cavolinia tridentata affinis (part) Tesch, 1913: 51, Tesch 1948: 25, fig. 21 C-D; Cavolinia tridentata forma affinis van der Spoel, 1967: 96.

\section{Material}

$19^{\circ} 37.7^{\prime} S 108^{\circ} 27.7^{\prime} \mathrm{W}$ (U.S.N.M. 670196) (fig. 5i).

\section{Description}

The shell is small in relation to the other formae, though the average size seems still higher than in the forma occidentalis. The caudal spine is curved dorsad in some specimens, but usually the spine is straight and projecting a little caudad, so that its axis makes an angle with the shell axis. This oblique position is typical for all the Indo-Pacific formae though it occurs always to a lesser extent than in the forma occidentalis. The usually opaque shell shows a slightly vaulted dorsal surface with normally developed longitudinal ribs. The dorsal aperture lip is rounded and the lateral sides show no keels. The lateral spine points are not or only slightly directed caudad. The arch-shaped rib at the base of the dorsal aperture lip is not as strong as in most other formae. The shell margin between the caudal and lateral spines is concave. The aperture has a lunar shape. The ventral aperture lip is relatively small while the ventral side is strongly vaulted. This side is, however, not circle round in profile view like in the next forma as the greatest shell thickness is found anterior to the middle. 
Growth lines and shell structures are very faint. The number of transversal striae on the ventral side is very high. The shell colour consists of a light purple brown hue over the whole shell. The shell length varies between 8.5 and $11.5 \mathrm{~mm}$, the width varies between 6.0 and $8.0 \mathrm{~mm}$; too few specimens were available to give averages.

\section{Range}

This forma occurs in the Southeastern Pacific (centre X). Type locality: South Pacific between $30^{\circ}$ and $34^{\circ} \mathrm{S}$ and between $80^{\circ}$ and $92^{\circ} \mathrm{E}$ (Parislongitude). The two syntypes are kept dry in the Museum of Natural History at Paris, the adult specimen (11.4 mm length, $7.2 \mathrm{~mm}$ width) is indicated as lectotype, the young specimen (11.2 $\mathrm{mm}$ length, $6.8 \mathrm{~mm}$ width) is indicated as paralectotype.

The two specimens forming the type material are in all probability less "typical" for this forma as they are representing intermediate specimens.

Cavolinia tridentata forma occidentalis Dall, 1908. Figs. 5h; 6g.

\section{Synonymy}

Hyalaea affinis (non Sowerby, 1878, non Fryer, 1869) (part) d'Orbigny, 1836: 91; Cavolinia tridentata var. affinis (part) Tesch, 1904: 39, pl. 2, fig. 32; McGowan, unpubl.: 129; Cavolinia occidentalis Dall, 1908: 223, pl. 12, fig. 1; Dall, 1921: 59; Cavolinia tridentata affinis (part) Tesch, 1913: 51; Tesch, 1948: 25, fig. $21 \mathrm{C}-\mathrm{D}$; Cavolinia tridentata forma tridentata (part) van der Spoel, 1967: 94.

\section{Material}

Taka Islet, Marshall Isls. (U.S.N.M. 615457); $40^{\circ} 11^{\prime} \mathrm{N}$ $125^{\circ} 9^{\prime}$ W (U.S.N.M. 253050); S. coast of Oahu; Hawaii Isls. (U.S.N.M. 334809) (fig. 5h); $00^{\circ} 58.5^{\prime} \mathrm{N} 122^{\circ} 42.5^{\prime} \mathrm{E}$ (Siboga Exped. sta. 116, Z.M.A.).

\section{Description}

The shell is very small in relation to those of the other formae of this species. In general appearance the specimens resemble Cavolinia uncinata, though the caudal spine is completely straight. The opaque shell shows a relatively strongly vaulted dorsal surface with three moderately developed central ribs and two faintly developed lateral ribs. The dorsal aperture lip is separated from the dorsal surface by a prominent arch-shaped rib. The dorsal lip is rounded and the lateral sides show no keels. The lateral spine tops are not or only slightly directed caudad. The shell margin between the caudal spine and lateral spines is composed of a more or less straight section and a concave part. The ventral aperture lip is very small in comparison with the other forms. The ventral side is strongly vaulted, in profile view it is perfectly circle round. The aperture has a triangular lunar shape. The sculpture on the shell consists of growth lines and up to 20 transversal ribs on the lateral side. The shell shows only a light brown or yellowish hue colour pattern, the upper lip and lateral sides are lighter. The shell length varies between 7.5 and $11.5 \mathrm{~mm}$, the width between 5.5 and 8.5 $\mathrm{mm}$, with averages of 10.3 and $6.6 \mathrm{~mm}$ respectively.

\section{Range}

This forma occurs in the North East Pacific (centre XI). Type locality: $38^{\circ} 4^{\prime} \mathrm{N} 137^{\circ} \mathrm{W}$, coll. Dall. The holotype (U.S.N.M. 110591) and four paratypes (U.S.N.M. 110590) are kept dry in the United States National Museum at Washington D.C.
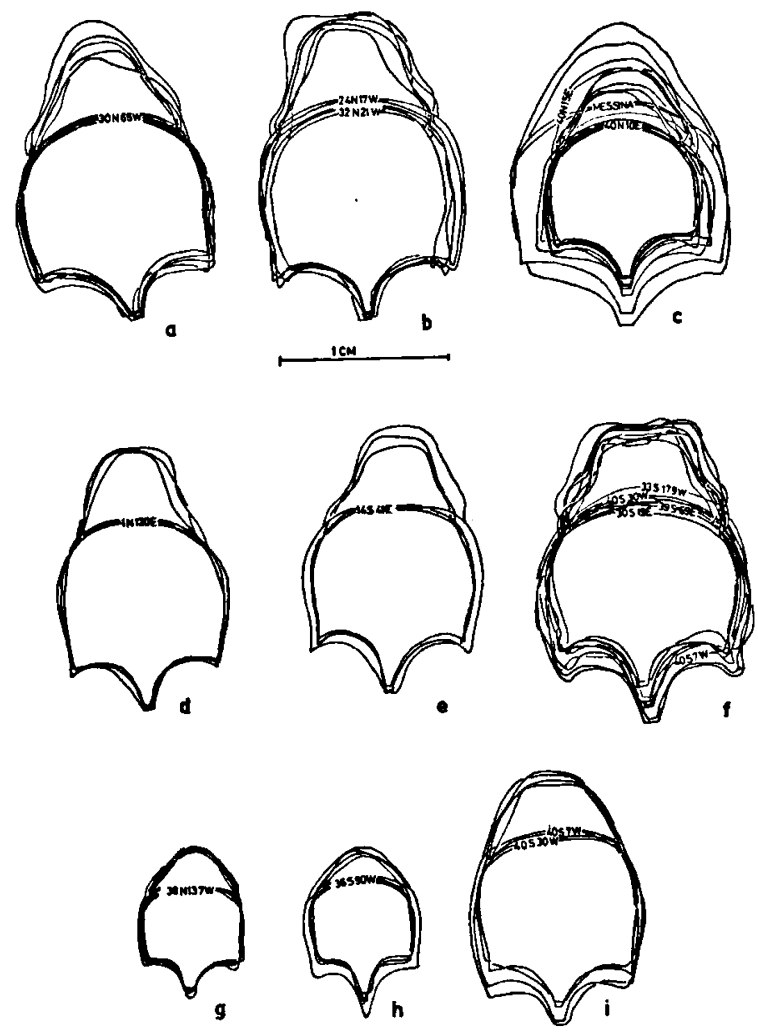

Fig. 6. Outlines of shells of Cavolinia tridentata in ventral view made with the camera lucida of the formae bermudensis (a), dakarensis (b), tridentata (c), teschi (d), danae (e), kraussi (f), occidentalis (g), affinis (h), and atlantica (i). 
KEY TO THE FORMAE OF

\section{CAVOLINIA TRIDENTATA}

The great resemblance between the formae makes it necessary to give a key for their identification. In fig. 6 the outlines of the different forms seen from the ventral side are given for comparison when using the key. During growth the shell shows two remarkable changes. In older specimens the shell is thicker than in the younger minute stages so that the shell thickness is variable. Secondly, the upper aperture lip continues growing for a long period. Very young specimens show always a rounded aperture lip, while in older specimens an additional part is formed which tends to be more blunt. Shell thickness is not used in the key. In point 3 of the key the aperture lip is given as discriminating character and it should be mentioned that older specimens show sometimes a small blunt addition to the lip though it is considered "rounded" in the key. In the formae kraussi, dakarensis and danae, however, a large blunt, or straight aperture part is found in all specimens, whereas the other formae show only a small, blunt aperture part of maximal $3 \mathrm{~mm}$ in some of the older specimens.

1 a) Shell triangular in ventral view, dorsal aperture lip rounded . . . . . . . . . forma tridentata

b) Shell not triangular or without rounded aperture lip . . . . . . . . . . . . . . . . 2

2 a) Shell with keels along the lateral sides . . . . .

b) $\cdot$ - $\cdot \cdot \cdot \cdot \cdot \cdot \cdot$ forma kraussi

a) Dorsal aperture lip rounded. .54

b) Dorsal aperture lip with straight anterior margin or with two points........ . . . 8

4 a) Shell longer than $13.5 \mathrm{~mm}$. . . . . . . . 5

b) Shell length less than $13.5 \mathrm{~mm}$. . . . . . . 7

5 a) Lateral spine points not directed caudad . . . . . . . . . . . . . . . forma bermudensis

b) Lateral spine points directed usually caudad . . 6

6 a) Caudal spine length $1 / 3$ of the distance between the lateral spine tops, the outline of lateral sides and dorsal aperture lip is not continuous . . . . . . forma teschi

b) Caudal spine length $1 / 4$ of the distance between the lateral spine tops, the outline of lateral sides and dorsal aperture lip is continuous without interruption . . . . . . . . . . . forma atlantica

7 a) Ventral side in lateral view perfectly circle round, caudal spine straight . . . . forma occidentalis

b) Ventral side in lateral view not circle round but bulging more in cranial direction, caudal spine directed or bended caudad . . . . forma affinis

8 (Lateral spine not curved caudad, or lateral keels present see 4)

a) Lateral spine curved caudad, shell larger than 16.5 $\mathrm{mm}$. . . . . . . . . . forma dakarensis

b) Lateral spine curved caudad, shell smaller than $\mathbf{1 6 . 5}$ $\mathrm{mm}$. . . . . . . . . . . forma danae

\section{SUMMARY}

The geographical variation in Cavolinia tridentata is discussed, and nine formae of the species are described. The material described originally from the Mediterranean belongs to the endemic forma tridentata. The forma bermudensis from the Western Atlantic between $5^{\circ}$ and $50^{\circ} \mathrm{N}$, the forma dakarensis from the Eastern Atlantic between $5^{\circ}$ and $65^{\circ} \mathrm{N}$, and the forma atlantica from the Southern Atlantic are described as formae new to science. In the southern oceans south of about $30^{\circ} \mathrm{S}$ the forma kraussi is found. In the Northeastern Pacific the forma occidentalis is found and in the Southeastern Pacific the forma affinis is present. The three latter formae were already known but a general picture of their distribution is for the first time given in this paper. For the Indian Ocean and Indo-Malayan and Central Pacific waters two formae new to science are described. In the Indian Ocean the forma danae is found and in the Indo-Malayan waters a population of the forma teschi is found which penetrates into the Central Pacific.

The more or less intensive interbreeding between the formae is discussed.

\section{LITERATURE}

AbildganRd, P. C., 1791. Nyere efterretning om det skaldyr fra middelhavet, form Forskål har beskrevet under navn of Anomia tridentata. Skr. Naturh.-Selsk. Kjøbenhavn, 1 (2) : $171-175$.

BonS, J. E. V., 1886. Spolia Atlantica. Bidrag til Pteropodermes. Morfologi og systematik samt til kundskaben om deres geografiske udbredelse. Vidensk. Selsk. Skr. 6 Raekke, naturv. mathemat. Afd. IV (1) : $1-231$, pls. $1-22$.

DALL, W. H., 1908. The Mollusca and the Brachiopoda. Bull. Mus. comp. Zool. Harv., 43 (6) : 205-487, pls. 1-22.
,- 1921 . Summary of the marine shell-bearing mollusks of the North West Coast of America, from San Diego, California to the Polar Sea, mostly contained in the collection of the United States National Museum, with illustrations of hitherto unfigured species. Bull. U.S. natn. Mus., $112: 1-217$, pls. $1-22$.

Forskål, P., see Niebuhr, C.

FrYer, G. E., 1869. A contribution to our knowledge of pelagic Mollusca. J. Asiat. Soc. Beng., 38 (2) : 259 268, pl. 21.

KraUSS, F., 1848. Die Südafrikanischen Mollusken. Ein Beitrag zur Kenntniss der Mollusken des Kap- und 
Natallandes und zur geographischen Verbreitung derselben, mit Beschreibung und Abbildung der neuen Arten: i-iv, 1-140, pls. I-VI. (Ebner \& Seubert, Stuttgart).

LiNNAEUS, C., 1758. Systema naturae per regna tria naturae, secundum classes, ordines, genera, species, cum characteribus, differentiis, synonymis, locis. Tomus I. Editio decima, reformata: i-iv, 1-824. (L. Salvii, Holmiae).

McGowan, J. A. (unpubl.). The systematics, distribution and abundance of Euthecosomata of the North Pacific: 1-197. (Ph. D. Thesis Univ. of California at San Diego, 1960).

NIEBUHR, C., 1775 (MS. P. ForSKR̊L). Descriptiones animalium avium, amphibiorum, piscium, insectorum, vernium; quae in itinere Orientali observavit Petrus Forskål. Prof. Haun. Post mortem auctoris edidit Carsten Niebuhr. Adjuncta est materia medica Kahirina atque tabula Maris Rubri geographica : 1-164, 1 map. (Mölleri, Hauniae).

,- 1776 . Icones rerum naturalium quas in itinere Orientali depingi curavit Petrus Forskål, Prof. Haun. Post mortem auctoris ad Regis mandatum aeri incisas edidit Carsten Niebuhr: 1-15, pls. XXI-XLIII. (Mölleri, Hauniae).

OrbignY, A. D', 1835-1846. Voyage dans l'Amérique méridionale (...), exécuté pendant les années 1826 , $1827,1828,1829,1830,1831,1832$ et $1833, \ldots \mathrm{V}(3)$. Mollusques: i-vi, i-xliii, 1-758. Atlas des mol- lusques (1846): i-iv, pls. 1-85. (Bertrand, Paris; Levrault, Strasbourg).

PhilipPI, R. A., 1853. Handbuch der Conchyliologie und Malacozoologie: $\mathrm{i}-\mathrm{xx}, 1-548$. (E. Anton, Halle).

Schiemenz, P., 1906. Die Pteropoden der Plankton Expedition. Ergebn. Plankton-Exped., II (F) (b) : 130, fig. 1, pls. I-III.

SPOEL, S. VAN DER, 1967. Euthecosomata, a group with remarkable developmental stages (Gastropoda, Pteropoda) : 1-375. (Noorduyn \& Zn., Gorinchem).

,- 1970 . Morphometric data on Cavoliniidae, with notes on a new form of Cuvierina columnella (Rang, 1827) (Gastropoda, Pteropoda). Basteria, 34 (5/6) : 103151.

,- 1971 . Some problems in infraspecific classification of holoplanktonic animals. Zeitschr. Syst. Evol., 9 (2) : $107-138$.

TesCH, J. J., 1904. The Thecosomata and Gymnosomata of the Siboga Expedition. Siboga Exped., LII [16] : 1-92, pls. I-VI.

-, 1913. Pteropoda. Tierreich, 36 : i-xvi, 1-154.

,- 1948 . The thecosomatous pteropods. II. The IndoPacific. Dana Rep., V (30) : 1-45, pls. 1-3.

-, (unpubl.). Pteropods and heteropods. Biol. Res. Snellius Exp. (MS.).

WolfF, T., 1968. The Danish Expedition to "Arabia Felix" (1761-1767). Bull. Inst. océanogr. Monaco. No. spécial 2 [Congr. int. Hist. Océanogr., 1] : 581601. 